\title{
Host-based identification is not supported by morphometrics in natural populations of Gyrodactylus salaris and G. thymalli (Platyhelminthes, Monogenea)
}

\author{
K. OLSTAD ${ }^{1 *}$ A. P. SHINN ${ }^{2}$, L. BACHMANN ${ }^{1}$ and T. A. BAKKE ${ }^{1}$ \\ ${ }^{1}$ Natural History Museum, Department of Zoology, University of Oslo, P.O. Box 1172, NO-0318 Oslo, Norway \\ ${ }^{2}$ Institute of Aquaculture, University of Stirling, Stirling FK9 4LA, UK
}

(Received 15 May 2007; revised 25 fune 2007; accepted 16 August 2007; first published online 16 August 2007)

S UMMAR Y

Gyrodactylus salaris is a serious pest of wild pre-smolt Atlantic salmon (Salmo salar) in Norway. The closely related G. thymalli, originally described from grayling (Thymallus thymallus), is assumed harmless to both grayling and salmon. The 2 species are difficult to distinguish using traditional, morphometric methods or molecular approaches. The aim of this study was to explore whether there is a consistent pattern of morphometrical variation between G. salaris and G. thymalli and to analyse the morphometric variation in the context of 'diagnostic realism' (in natural populations). Specimens from the type-material for the 2 species are also included. In total, 27 point-to-point measurements from the opisthaptoral hard parts were used and analysed by digital image processing and uni- and multivariate morphometry. All populations most closely resembled its respective type material, as expected from host species, with the exception of $G$. thymalli from the Norwegian river Trysilelva. We, therefore, did not find clear support in the morphometrical variation among G. salaris and G. thymalli for an a priori species delineation based on host. The present study also indicates an urgent need for more detailed knowledge on the influence of environmental factors on the phenotype of gyrodactylid populations.

Key words: morphology, systematics, Atlantic salmon, Salmo salar, grayling, Thymallus thymallus.

\section{INTRODUCTION}

Gyrodactylids are ubiquitous ectoparasites on the skin and gills of teleost fish both in marine and freshwater ecosystems (Bakke et al. 2007). The most recent species compilation lists 409 gyrodactylid species (Harris et al. 2004). Until the mid-1990s, most Gyrodactylus species were identified by comparing the morphology of the opisthaptoral hard parts. Over recent years, the application of molecular markers in the taxonomy and systematics of Gyrodactylus species has increased, e.g., the sequencing of the internal transcribed spacers (ITS-1 and ITS-2) of nuclear ribosomal DNA (rDNA). Ziętara and Lumme (2002) showed that many Gyrodactylus species can be discriminated by internal transcribed spacer (ITS) sequences, and subsequent phylogenetic analyses yielded tree topologies that were basically consistent with those of classical taxonomy. However, G. salaris Malmberg, 1957 cannot be differentiated from its closest relative G. thymalli Žitňan, 1960 by means of ITS-1 and ITS-2 sequences (Cunningham, 1997), even considering parasites from a wide geographical range (Ziętara and Lumme, 2002).

* Corresponding author: Natural History Museum, Department of Zoology, University of Oslo, P.O. Box 1172, NO-0318 Oslo, Norway. Tel: +47228518 23. Fax: +47228518 37. E-mail: kjetil.olstad@nhm.uio.no
G. salaris has seriously hampered the natural juvenile production of Atlantic salmon, Salmo salar L., in Norway over the past 3 decades and has caused great harm both in ecological and economic terms (Johnsen et al. 1999; Mo et al. 2004), whereas $G$. thymalli is considered harmless to any of its known potential hosts. However, Jørgensen et al. (2007) and Olstad et al. (2007) have recently described 2 strains of $G$. salaris with restricted infectivity and reproduction on Atlantic salmon.

Several approaches using different markers have addressed the taxonomy and systematics of $G$. salaris and $G$. thymalli. To date, the mitochondrial cytochrome $c$ oxidase subunit 1 gene $(\cos 1)$ is the only marker allowing for a genetic discrimination of populations of G. salaris and G. thymalli (see e.g., Hansen et al. 2003, 2006; Meinilä et al. 2004). However, the 2 species differ in host preference (Soleng and Bakke, 2001; Bakke et al. 2002; Sterud et al. 2002), which is an important characteristic for considering $G$. salaris and $G$. thymalli different species. Discrimination of the 2 species based on multivariate statistics on morphometric measurements have proved possible but only a few populations (McHugh et al. 2000; Shinn et al. 2004) were included in these studies.

In the present study, we explored whether there is a consistent pattern of morphometrical variation between $G$. salaris and $G$. thymalli over a broad range 
of natural populations by using a set of 'traditional' point-to-point morphometric measurements. Such morphometric measurements are known to be affected by environmental parameters, such as temperature (see Malmberg, 1970; Mo, $1991 a, b, c$; Dmitrieva and Dimitrov, 2002; Davidova et al. 2005) that may impede an objective analysis of opisthaptor morphology. However, we were interested to investigate the 'diagnostic realism' in studying natural populations rather than analysing populations of gyrodactylids raised experimentally in a constant environment. To test whether $G$. salaris and $G$. thymalli are 1, 2, or more than 2 species, sample locations were chosen to comprehensively reflect the known variation in $\operatorname{cox} 1$ genealogy.

\section{MATERIALS AND METHODS}

\section{Sampling of Gyrodactylus}

In total, 10 populations have been sampled and 168 specimens measured. Four Gyrodactylus populations were sampled from wild infected Atlantic salmon populations, namely, the rivers Skibotnelva (northern Norway), Rauma (north-western Norway), Drammenselva (southern Norway), and Göta älv (south-western Sweden). In the 3 Norwegian rivers, serious gyrodactylosis caused by $G$. salaris has been documented (Johnsen et al. 1999). One sample was collected from rainbow trout (Oncorhynchus mykiss Walbaum) (from a fish-farm in lake Bullaren, south-western Sweden), and one sample was collected from Arctic charr (Salvelinus alpinus L.) in lake Pålsbufjord (central South-Norway). The population of Gyrodactylus in Lake Bullaren was identified as $G$. salaris by the OIE Reference Laboratory for Gyrodactylus (G. salaris) in Norway (Mo et al. 2004). The sample from Lake Pålsbufjord was confirmed as $G$. salaris based on ITS rDNA and cox 1 sequences (Robertsen et al. 2007). Four Gyrodactylus populations were sampled from wild infected grayling (Thymallus thymallus L.) populations, namely Lake Lesjaskogsvatn (central SouthNorway), rivers Trysilelva (south-eastern Norway), Rena (south-eastern Norway) and Hnilec (Slovakia). The river Hnilec is one of the 2 type localities for G. thymalli according to Žitňan (1960) (see below). For the purpose of clarity, in this manuscript populations are referred to as G. salaris if recovered from Atlantic salmon and $G$. thymalli if recovered from grayling. Accordingly, the samples from Lake Bullaren and Lake Pålsbufjord will be discussed independently. Wild fish were either captured by electro-fishing, gill netting or by rod-fishing. Parasite specimens were isolated from fins taken from the host and stored in 96\% ethanol during transportation to the laboratory. The $\operatorname{cox} 1$ sequences of the presently analysed samples are presented in Hansen et al. (2003, 2006). Further details are listed in Table 1.

\section{Type-material}

Gyrodactylus salaris was first described by Malmberg (1957) from Atlantic salmon in the Hölle Laboratory on the Baltic river Indalsälv, Sweden. The original description was based on 1 individual from a sample collected in $1952^{1}$. Nevertheless, Malmberg prepared a total of 26 individuals from the same sample. The material is deposited in the Swedish Museum of Natural History, Stockholm. For the present study, 12 specimens from 'the type-sample' were photographed at the University of Stockholm using a Leica DC 300 camera mounted on a Leitz (Dialux) stereomicroscope under a $\times 63$ dry and $a \times 100$ immersion-oil objective. For scaling of the pictures, a stage micrometer from Albert Sass, Berlin (2 mm in 200 parts) was used. Measurements were performed on the Oslo Leica IM1000 v.4.0 software. (G. salaris ID. : 7089-7100; no. 7089 being registered as lectotype and the others as paralectotypes (Sven Boström, personal communication)).

Gyrodactylus thymalli was first described by Žitňan (1960) from grayling from the rivers Hnilec and Hron, Slovak Republic ${ }^{2}$. The material is deposited in the East Slovak Museum, Kosice, the Slovak Republic. A total of 12 individuals were included in the description. Of these, 6 were available for analysis in the present work (ID. no. Z-11229/ 1-6). The material was photographed and analysed at the Department of Zoology, Natural History Museum, University of Oslo, Norway according to the procedures described below.

\section{Morphometry}

For the morphometric analyses, individual Gyrodactylus specimens $(n=12-30)$ from each population were removed from fins and fixed in $96 \%$ ethanol. The opisthaptors were cut off and the opisthaptoral hard parts were subsequently prepared using a method slightly modified after Harris et al. (1999). The haptors were digested in $75 \mathrm{~mm}$ Tris, $10 \mathrm{~mm}$

${ }^{1}$ Ergens (1983) re-described what he assumed to be the holotype of $G$. salaris, something that has turned out to be due to a misunderstanding. Malmberg did not assign any holotype-status in his original description (Malmberg, 1957). Furthermore, the individual Ergens described was from a sample taken in Hölle dating to 1957, and not from the original 1952 type-material (G. Malmberg, personal communication). The infection in Hölle Laboratory was chemically eliminated several times between 1952 and 1957 (G. Malmberg, personal communication).

2 Žitňan's (1960) description was based on 12 individuals of which 2 were collected from the river Hron and 10 from the river Hnilec. Although not describing a holotype, Žitňan marked 1 (and only 1) of the slides "TYP" (ID. no.: z-11229/6 - sampled at Hnilec by Starà Voda) (V. Dudinak, personal communication). Ergens (1983) adapting the original description, highlighted the river Hron as the type locality, although this was not specifically detailed by Žitňan (1960). 
Table 1. The Gyrodactylus populations, place of analyses and designation of the mitochondrial haplotype clades

( $\mathrm{UoO}=$ University of Oslo; $\mathrm{UoS}=$ University of Stirling.)

\begin{tabular}{|c|c|c|c|c|c|c|c|}
\hline \multirow[b]{2}{*}{$\begin{array}{l}\text { Natural } \\
\text { populations } \\
\text { (country) }\end{array}$} & \multirow[b]{2}{*}{$\begin{array}{l}\text { Date of } \\
\text { sampling }\end{array}$} & \multirow[b]{2}{*}{$\begin{array}{l}\text { Temperature } \\
\text { at sampling }\end{array}$} & \multirow[b]{2}{*}{$\begin{array}{l}\text { Host species } \\
\text { (Sampling } \\
\text { method) }\end{array}$} & \multirow[b]{2}{*}{$\begin{array}{l}\text { Place of } \\
\text { analyses }\end{array}$} & \multicolumn{3}{|c|}{ Mitochondrial haplotype/clade according to: } \\
\hline & & & & & $\begin{array}{l}\text { Hansen } \\
\text { et al. } \\
(2003)\end{array}$ & $\begin{array}{l}\text { Meinilä } \\
\text { et al. } \\
(2004)\end{array}$ & $\begin{array}{l}\text { Hansen } \\
\text { et al. } \\
(2006)\end{array}$ \\
\hline $\begin{array}{l}\text { Drammenselva } \\
\text { (Norway) }\end{array}$ & 18.06 .02 & $14 \cdot 5{ }^{\circ} \mathrm{C}$ & $\begin{array}{l}\text { S. salar } \\
\text { (Electrofishing) }\end{array}$ & UoS & $\mathrm{F}-\mathrm{III}$ & $\begin{array}{l}\text { Sal F } \\
\text { Drammen - II }\end{array}$ & F - III \\
\hline $\begin{array}{l}\text { Skibotnelva } \\
\text { (Norway) }\end{array}$ & 20.09 .01 & $10 \cdot 5{ }^{\circ} \mathrm{C}$ & $\begin{array}{l}\text { S. salar } \\
\text { (Electrofishing) }\end{array}$ & $\begin{array}{l}\text { UoS; } \\
\text { UoO }\end{array}$ & B - I & Sal B Skibotn & $\mathrm{B}-\mathrm{I}$ \\
\hline $\begin{array}{l}\text { Rauma } \\
\text { (Norway) }\end{array}$ & 09.10 .01 & $7.8^{\circ} \mathrm{C}$ & $\begin{array}{l}\text { S. salar } \\
\text { (Electrofishing) }\end{array}$ & UoS & $\mathrm{A}-\mathrm{I}$ & Sal A Rauma & $\mathrm{A}-\mathrm{I}$ \\
\hline $\begin{array}{l}\text { Göta älv } \\
\text { (Sweden) }\end{array}$ & 13.11 .01 & $3{ }^{\circ} \mathrm{C}$ & $\begin{array}{l}\text { S. salar } \\
\text { (Electrofishing) }\end{array}$ & UoS & $\mathrm{E}-\mathrm{II}$ & $\begin{array}{l}\text { Sal E Göte } \\
\text { älv - I }\end{array}$ & $\mathrm{E}-\mathrm{II}$ \\
\hline $\begin{array}{l}\text { Bullaren }{ }^{1} \\
\text { (Sweden) }\end{array}$ & 13.05 .02 & $12^{\circ} \mathrm{C}$ & O. mykiss & $\mathrm{UoO}$ & $\mathrm{F}-\mathrm{III}$ & Onc-II & $\mathrm{F}-\mathrm{II}$ \\
\hline $\begin{array}{l}\text { Pålsbufjord } \\
\text { (Norway) }\end{array}$ & $\begin{array}{l}\text { Aug-Oct. } \\
2003^{2}\end{array}$ & $8-15^{\circ} \mathrm{C}$ & $\begin{array}{l}\text { S. alpinus } \\
\text { (Gill netting) }\end{array}$ & UoS & n.a. & n.a. & n.a. \\
\hline $\begin{array}{l}\text { Trysilelva } \\
\text { (Norway) }\end{array}$ & $28 \cdot 05 \cdot 04$ & $10^{\circ} \mathrm{C}$ & $\begin{array}{l}\text { T. thymallus } \\
\text { (Fly-fishing) }\end{array}$ & $\mathrm{UoO}$ & $\mathrm{G} / \mathrm{H}-\mathrm{IV}$ & $\begin{array}{l}\text { Thy G Trysilelva, } \\
\text { Thy H } \\
\text { Trysilelva - V }\end{array}$ & $\mathrm{G} / \mathrm{H} / \mathrm{P}-\mathrm{IV}$ \\
\hline $\begin{array}{l}\text { Lesjaskogsvatn } \\
\text { (Norway) }\end{array}$ & 14.06 .03 & $4 \cdot 5^{\circ} \mathrm{C}$ & $\begin{array}{l}\text { T. thymallus } \\
\text { (Fish trap) }\end{array}$ & UoS & n.a. & n.a. & $\mathrm{Q}-\mathrm{V}$ \\
\hline $\begin{array}{l}\text { Rena } \\
\text { (Norway) }\end{array}$ & 24.06 .06 & $8^{\circ} \mathrm{C}$ & $\begin{array}{l}\text { T. thymallus } \\
\text { (Fly-fishing) }\end{array}$ & $\mathrm{UoO}$ & $\mathrm{I} / \mathrm{L}-\mathrm{V}$ & $\begin{array}{l}\text { Thy Rena, } \\
\text { Thy I Rena }\end{array}$ & $\mathrm{I} / \mathrm{L}-\mathrm{V}$ \\
\hline $\begin{array}{l}\text { Hnilec } \\
\text { (Slovakia) }\end{array}$ & 20.05 .03 & $12{ }^{\circ} \mathrm{C}$ & $\begin{array}{l}\text { T. thymallus } \\
\text { (Electrofishing) }\end{array}$ & UoS & n.a. & n.a. & $\mathrm{N}-\mathrm{VI}$ \\
\hline
\end{tabular}

1 Samples of O. mykiss originated from a fish farm in Lake Bullaren.

2 Sampling in Pålsbufjord performed during specified period.

EDTA, $5 \%$ SDS and $100 \mathrm{mg} / \mathrm{ml}$ proteinase $\mathrm{K}$, $\mathrm{pH} 8 \cdot 0$. After washing twice in $\mathrm{H}_{2} \mathrm{O}$, the released hard parts were fixed in ammonium picrate glycerine (Malmberg's fixative). The digital image analyses were performed by only 1 person (K. Olstad), but at 2 different laboratories; the Institute of Aquaculture, University of Stirling, UK, and at the Department of Zoology, Natural History Museum, University of Oslo, Norway (for details, see Table 1). At the University of Stirling, specimens were photographed using a JVC KY-F30B 3CCD camera with an interfacing $\times 2 \cdot 5$ top lens fitted to an Olympus $\mathrm{BH} 2$ compound microscope under a $\times 100$ oil objective, and measured using the Zeiss KS300 iC/Windows Release v.3.0 (1997) (Carl Zeiss Vision $5 \mathrm{GmbH}$, Munich, Germany/Imaging Associates Ltd, Thame, Oxfordshire, UK) software. At the Natural History Museum, University of Oslo, specimens were photographed using a Leica DC 500 camera mounted on a Leica DM $6000 \mathrm{~B}$ stereomicroscope under a $\times 100$ oil objective, and measured using the Leica IM1000 v.4.0 software.

A total of 27 point-to-point measurements were taken on each specimen. Of these, 23 were identical to the measurements described by Shinn et al. (2004), and with the same annotations. (i) Marginal hook (MH): total length (MHTL), shaft length (MHSHL), sickle length (MHSL), sickle proximal width (MHSPW), sickle toe length (MHSTL), sickle distal width (MHSDW), sickle aperture (MHAD), instep height (MHIH). (ii) Hamulus (H) : proximal shaft width (HPSW), aperture distance (HAD), point length (HPL), distal shaft width (HDSW), hamulus inner angle (HIA), inner curve length (HICL), shaft length (HSL), root length (HRL), total length (HTL). (iii) Ventral bar (VB): total length (VBTL), process to mid length (VBPML), median length (VBML), membrane length (VBMBL), centre length (VBCL), lateral length (VBLL), total width (VBTW), width (VBW), membrane maximal width (VBMMW) and process length (VBPL).

The 2 hamulus measurements, the aperture angle (HAA) and the point curve angle (HHPCA) used by Shinn et al. (2004), were not considered in this study. The 4 measurements VBCL, VBLL, VBW, and VBMMW represent new morphometric variables and are depicted in Fig. 1.

\section{Statistical analyses}

All statistical analyses as well as ordination were performed using the software PAST v.1.66 (Hammer et al. 2001). The hamulus inner angle (HIA) was transformed to the cosine in order to obtain linear functions prior to data analyses. Since 
marginal hook total length (MHTL) and shaft length (MHSHL) were not possible to obtain from the type materials, these measurements were omitted in the analyses.

Since photographing of the specimens and measuring of the sclerites were performed at 2 different localities with 2 different microscopes and software, the same specimens $(n=10)$ from a randomly chosen population (Skibotnelva) first measured at the University of Stirling, were re-measured at the Natural History Museum, Oslo. The nonparametric Bray-Curtis MANOVA was used to test whether the multivariate means of the 2 data-samples were equal.

Based on the hypothesis that the sampled individuals belong to 2 distinct species, k-means clustering preset for 2 groups was run on the total data-matrix. The cluster assignments in k-means clustering are initially random which implies that the results may differ from run to run. The procedure was therefore repeated $>10$ times. Clustering into 3 and 4 groups was also run in order to test alternative hypotheses regarding number of groups (e.g., groupings according to host-species).

In order to test the hypothesis that any 2 populations had equal multi-dimensional means, Wilk's lambda MANOVA and Hotelling's pairwise post-hoc comparisons were run. The Hotelling's pairwise post-hoc comparisons were run both with and without Bonferroni corrections. The low number of individuals available for study in this analysis in combination with the high number of variables made a dimensionality-reduction of the data-matrix necessary. Principal Component Analysis (PCA) scores on the variance-covariance matrix were therefore obtained, and the statistical tests run on a limited number of the PCA axis-scores (but maintaining $>95 \%$ of the total variation). For a numerical comparison of distances between population multivariate distributions, pair-wise Mahalanobis distances were calculated using S-PLUS 6.0, Professional Release 1.

\section{RESULTS}

The morphometric differences of 10 populations of the monogenean G. salaris on Atlantic salmon, rainbow trout and Arctic charr and $G$. thymalli on grayling, were studied. These particular Gyrodactylus populations were selected as they comprehensively represent mitochondrial haplogroups as described by Hansen et al. (2003, 2006) (Table 1), and are thus expected to represent the range of intra- and interspecific variation of $G$. salaris and $G$. thymalli. The assignment of mitochondrial haplotypes to parasite populations is in some instances based on the cytochrome oxidase I sequence of only 1 individual, hence intra-populational mitochondrial sequence variation cannot be excluded. Individual cytochrome

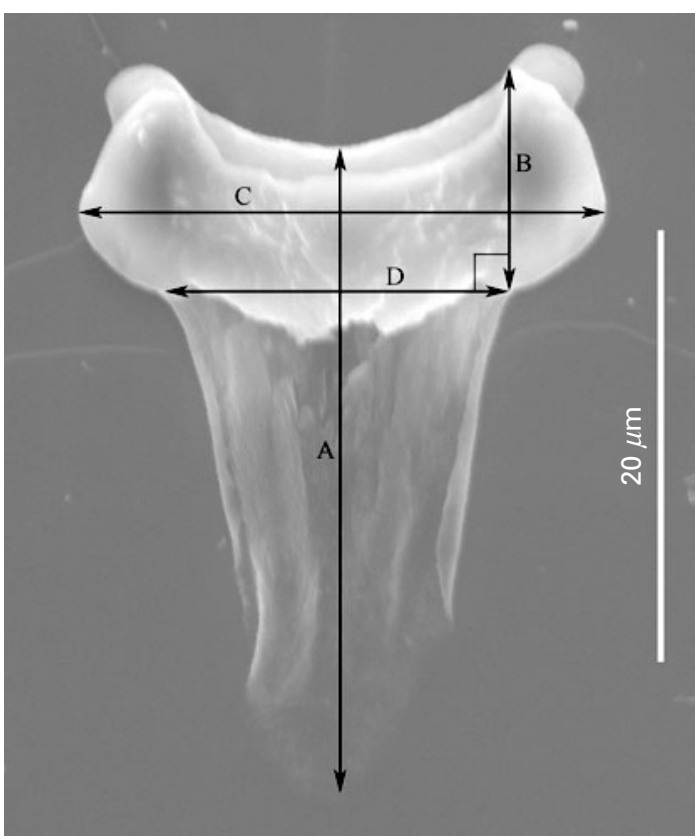

Fig. 1. Scanning electron micrograph (SEM) of the ventral bar (VB) from a Gyrodactylus specimen parasitizing grayling in the river Hnilec, Slovakia, illustrating the four new measurements. (A) Ventral bar centre length (VBCL): The distance between the top of the median bar and the distal part of the membrane, along a line following the centre of the structure. (B) Ventral bar lateral length (VBLL): The distance between an orthogonal line between ventral bar bases towards the membrane (measurement $\mathrm{D}$ ) to the distal top of the ventral bar (excluding the process). (C) Ventral bar width (VBW): The maximum width of the median portion of the ventral bar, excluding the processes. (D) Ventral bar membrane maximal width (VBMMW): the distance between the ventral bar bases towards the membrane.

oxidase I sequence data were not determined and intra-populational sequence variation was thus not considered in the present work.

The data obtained in the different labs were analysed together, as all measurements were performed by the same person and no significant differences were observed between any of the different instrumental set-ups used in the present investigations (non-parametric Bray-Curtis MANOVA $P=$ 0.297).

The type-material of $G$. salaris and $G$. thymalli constitutes whole-mounted worms that have been pre-treated with formalin. Such treatment is not favourable for light-microscope studies of the hard parts. The variance of the measurements from these individuals might thus be increased. Some individuals could not be reliably measured due to oblique positions of the hard parts and were thus discarded from the analyses $(G$. salaris measured: ID no. 7090, 7093, 7094, 7096, $7097-G$. thymalli measured: ID no. Z-11229/2-6). A summary of the 
morphometric measurements of the hard parts of the G. salaris and $G$. thymalli type-material is given in Table 2. Although the averages for the measurements of the marginal hook total length (MHTL), marginal hook shaft length (MHSAL), and marginal hook sickle length (MHSL) might indicate a clear grouping in 2 species in accordance with the a priori species delineation, the ranges between the groups substantially overlap. MHTL and MSHAL for the $G$. salaris and $G$. thymalli type-material were unfortunately impossible to obtain. Thus, the averages and ranges did not reveal a single measurement unambiguously grouping the populations in accordance with an a priori species delineation.

In the k-means clustering, both for 2 and 3 groups, the $G$. salaris type-material and the G. thymalli typematerial were categorized in separate groups (Table 3). When clustering into 2 groups, the Bullaren population (from rainbow trout) most closely resembled the ' $G$. salaris group' whereas the Pålsbufjord population (from Arctic charr) represented an intermediate group positioned between the G. salaris and G. thymalli groups (Table 3). The grayling parasites from Trysilelva resembled gyrodactylids collected from Atlantic salmon. The remaining populations of Gyrodactylus resembled type-material representing their respective species in accordance with the a priori species designations based on host species. When clustering into 3 groups, parasites sampled from Atlantic salmon and grayling basically followed the same pattern as when clustering into 2 groups, although some individuals from all populations but Hnilec were classified into Group 3 (Table 3). Individuals from both Bullaren (from rainbow trout) and Pålsbufjorden (from Arctic charr) were mainly classified into Group 3. With few exceptions, the pattern when clustering into 4 groups was consistent with the pattern when clustering into 3 groups (Exceptions: 1, 1 and 3 individuals from G. salaris type-material, Drammen and Skibotnelva, respectively, were classified into Group 4. Data not shown in table).

In a PCA-plot (run on the variance-covariance matrix) based on the measurements from all 10 populations and the type-material of both species (Fig. 2), the 2 populations representing the namebearing types separated well from each other. Furthermore, the populations Drammenselva, Skibotnelva, Rauma, Göta älv, Bullaren and Trysilelva apparently grouped with the $G$. salaris type-material, and the populations Hnilec, Lesjaskogsvatn and Rena with the G. thymalli type-material. Gyrodactylids collected from Arctic charr from Lake Pålsbufjord, on the other hand, appear to represent an intermediate group positioned between the main $G$. salaris and G. thymalli clusters. The graphical presentation of the PCA analysis did not reveal any groupings in the material related to $\operatorname{cox} 1$ phylogeny or to temperature/season of sampling. In principal components higher than 2, the PCA plot did not reveal any clear groupings of the data.

The scores from the PCA (run on the variancecovariance matrix) were used to identify a reduced number of linear combinations explaining a sufficient amount of the total variation in the data set. The first $9 \mathrm{PCs}$ explained $95.4 \% \quad(\mathrm{PC} 1-62.70 \%$; $\mathrm{PC} 2-9 \cdot 1 \%$; $\mathrm{PC} 3-6 \cdot 5 \%)$ of the total variation in the data set, and were thus considered to capture a sufficient amount of the variation in the 27 variables to be the only ones included in the subsequent multivariate analyses. According to established procedures in morphometric analyses, most of the variation explained in PC1 is due to size, particularly when the first PC explains a substantial percentage of the total variation in the data set (Jolicoeur and Mosiman, 1960; Reyment et al. 1984). Accordingly, the following multivariate analyses were both run on a data-matrix comprised of data from the first 9 PCs (PC1-PC9) and on a data matrix in which the data for PC1 had been removed (PC2-PC9; explaining $32.7 \%$ of the total variation in the data set). The latter is expected to be an analysis in which a major part of variation due to size is removed, thereby leaving variation principally attributable to changes in shape.

The MANOVA rejected the hypothesis of equal multidimensional means (Wilks-lambda, $P \ll 0 \cdot 05$ ) for all populations. This was observed both when including and excluding PC1. The Hotelling's $\mathrm{T}$ squared post-hoc tests gave significant differences $(P \ll 0 \cdot 05)$ between all populations when not Bonferroni corrected. Again, this was observed both with and without PC1. The Hotelling's T squared post-hoc tests when Bonferroni corrected, with few exceptions (Table 4) also gave significant results, despite very low statistical power. When analysing PC1-PC9, cases where the hypothesis of equality could not be rejected involved the salmon parasites from Drammenselva, Skibotnelva, Rauma, and Göta älv as well as the rainbow trout parasites from Bullaren. If removing the first PC, cases where the hypothesis of equality could not be rejected also involved the salmon parasites from Drammenselva, Skibotnelva, Rauma, and Göta älv. Additionally, equality could not be rejected between the grayling parasites from Lesjaskogsvatn and the salmon parasites from Drammenselva, Skibotnelva, and Rauma or between the grayling parasites from Hnilec and the salmon parasites from Skibotnelva and Rauma.

The Mahalanobis distances between the populations are listed in Table 5. For PC1-9 the magnitude of the distances indicates a grouping of the $G$. salaris populations on Atlantic salmon from Drammenselva, Skibotnelva, Rauma and Göta älv. Compared to these pairwise distances, the Mahalanobis distances between the G. salaris populations on rainbow trout (Bullaren) and the other 
Table 2. Summary of the morphometric measurements for the 10 Gyrodactylus populations analysed in this study

(A detailed explanation of abbreviations is provided in the Materials and Methods section. Each measured feature is given in micrometres ( $\mu$ m) except HIA, for which the measurements are given in degrees, followed by the standard deviation and the range (in parentheses). $n-$ Number of specimens measured. ${ }^{*}-$ Rainbow trout. ** - Arctic charr. *** - Grayling. Others hosted by Atlantic salmon.)

\begin{tabular}{|c|c|c|c|c|c|c|c|c|c|c|c|c|}
\hline & $\begin{array}{l}\text { Drammen } \\
\text { selva } \\
n=12\end{array}$ & $\begin{array}{l}\text { Skibotnelva } \\
n=14\end{array}$ & $\begin{array}{l}\text { Rauma } \\
n=12\end{array}$ & $\begin{array}{l}\text { Göta älv } \\
n=17\end{array}$ & $\begin{array}{l}\text { Bullaren* } \\
n=14\end{array}$ & $\begin{array}{l}\text { Pålsbu** } \\
n=30\end{array}$ & $\begin{array}{l}\text { Hnilec**** } \\
n=15\end{array}$ & $\begin{array}{l}\text { Lesjasko } \\
\text { gsvatn*** } \\
n=14\end{array}$ & $\begin{array}{l}\text { Trysilelva**** } \\
n=15\end{array}$ & $\begin{array}{l}\text { Rena**** } \\
n=18\end{array}$ & $\begin{array}{l}\text { G. salaris, } \\
\text { paralecto } \\
\text { types } \\
n=5\end{array}$ & $\begin{array}{l}\text { G. thymalli, } \\
\text { syntypes } \\
n=4\end{array}$ \\
\hline \multicolumn{13}{|l|}{ Marginal hook } \\
\hline MHTI & $\begin{array}{l}37 \cdot 9 \pm 0 \cdot 9 \\
(36 \cdot 3-39 \cdot 5)\end{array}$ & $\begin{array}{l}39 \cdot 5 \pm 1 \cdot 1 \\
(37 \cdot 7-41 \cdot 4)\end{array}$ & $\begin{array}{l}39 \cdot 6 \pm 0 \cdot 9 \\
(37 \cdot 9-41 \cdot 0)\end{array}$ & $\begin{array}{l}39 \cdot 9 \pm 1 \cdot 0 \\
(38 \cdot 5-42 \cdot 5)\end{array}$ & $\begin{array}{l}38 \cdot 9 \pm 1 \cdot 1 \\
(37 \cdot 3-40 \cdot 7)\end{array}$ & $\begin{array}{l}40 \cdot 2 \pm 1 \cdot 1 \\
(38 \cdot 2-42 \cdot 6)\end{array}$ & $\begin{array}{l}41 \cdot 7 \pm 0 \cdot 9 \\
(40 \cdot 3-43 \cdot 5)\end{array}$ & $\begin{array}{l}43 \cdot 0 \pm 0 \cdot 7 \\
(42 \cdot 2-44 \cdot 4)\end{array}$ & $\begin{array}{l}41 \cdot 7 \pm 1 \cdot 0 \\
(39 \cdot 5-43 \cdot 0)\end{array}$ & $\begin{array}{l}43 \cdot 3 \pm 1 \cdot 1 \\
(41 \cdot 4-45 \cdot 3)\end{array}$ & & \\
\hline MHSHL & $\begin{array}{l}30 \cdot 7 \pm 0 \cdot 9 \\
(29 \cdot 2-32 \cdot 4)\end{array}$ & $\begin{array}{l}31 \cdot 9 \pm 1 \cdot 0 \\
(30 \cdot 3-33 \cdot 3)\end{array}$ & $\begin{array}{l}32 \cdot 1 \pm 0 \cdot 9 \\
(30 \cdot 6-33 \cdot 3)\end{array}$ & $\begin{array}{l}32 \cdot 7 \pm 0 \cdot 8 \\
(31 \cdot 4-34 \cdot 6)\end{array}$ & $\begin{array}{l}31 \cdot 6 \pm 1 \cdot 0 \\
(30 \cdot 1-33 \cdot 1)\end{array}$ & $\begin{array}{l}32 \cdot 8 \pm 0 \cdot 9 \\
(30 \cdot 9-34 \cdot 4)\end{array}$ & $\begin{array}{l}33 \cdot 9 \pm 0 \cdot 8 \\
(32 \cdot 8-35 \cdot 6)\end{array}$ & $\begin{array}{l}35 \cdot 1 \pm 0 \cdot 9 \\
(33 \cdot 8-36 \cdot 7)\end{array}$ & $\begin{array}{l}34 \cdot 2 \pm 0 \cdot 9 \\
(32 \cdot 3-35 \cdot 2)\end{array}$ & $\begin{array}{l}35 \cdot 3 \pm 1 \cdot 0 \\
(33 \cdot 4-37 \cdot 1)\end{array}$ & & \\
\hline MHSL & $\begin{array}{l}7 \cdot 7 \pm 0 \cdot 2 \\
(7 \cdot 5-7 \cdot 9)\end{array}$ & $\begin{array}{l}8 \cdot 0 \pm 0 \cdot 3 \\
(7 \cdot 6-8 \cdot 6)\end{array}$ & $\begin{array}{l}8 \cdot 1 \pm 0 \cdot 2 \\
(7 \cdot 8-8 \cdot 3)\end{array}$ & $\begin{array}{l}7 \cdot 9 \pm 0 \cdot 3 \\
(7 \cdot 3-8 \cdot 6)\end{array}$ & $\begin{array}{l}8 \cdot 1 \pm 0 \cdot 3 \\
(7 \cdot 7-8 \cdot 5)\end{array}$ & $\begin{array}{l}7 \cdot 9 \pm 0 \cdot 2 \\
(7 \cdot 6-8 \cdot 4)\end{array}$ & $\begin{array}{l}8 \cdot 3 \pm 0 \cdot 2 \\
(7 \cdot 9-8 \cdot 7)\end{array}$ & $\begin{array}{l}8 \cdot 6 \pm 0 \cdot 2 \\
(8 \cdot 3-8 \cdot 9)\end{array}$ & $\begin{array}{l}8 \cdot 4 \pm 0 \cdot 3 \\
(7 \cdot 8-8 \cdot 8)\end{array}$ & $\begin{array}{l}8 \cdot 7 \pm 0 \cdot 3 \\
(8 \cdot 3-9 \cdot 1)\end{array}$ & $\begin{array}{l}8 \cdot 6 \pm 0 \cdot 7 \\
(7 \cdot 5-9 \cdot 3)\end{array}$ & $\begin{array}{l}8 \cdot 7 \pm 0 \cdot 2 \\
(8 \cdot 4-9 \cdot 0)\end{array}$ \\
\hline MHSPW & $\begin{array}{l}5 \cdot 2 \pm 0 \cdot 2 \\
(4 \cdot 7-5 \cdot 4)\end{array}$ & $\begin{array}{l}5 \cdot 5 \pm 0 \cdot 3 \\
(5 \cdot 1-6 \cdot 1)\end{array}$ & $\begin{array}{l}5 \cdot 4 \pm 0 \cdot 3 \\
(5 \cdot 1-6 \cdot 0)\end{array}$ & $\begin{array}{l}5 \cdot 5 \pm 0 \cdot 3 \\
(4 \cdot 7-5 \cdot 9)\end{array}$ & $\begin{array}{l}5 \cdot 2 \pm 0 \cdot 2 \\
(4 \cdot 9-5 \cdot 6)\end{array}$ & $\begin{array}{l}5 \cdot 3 \pm 0 \cdot 3 \\
(5 \cdot 0-6 \cdot 2)\end{array}$ & $\begin{array}{l}5 \cdot 4 \pm 0 \cdot 3 \\
(4 \cdot 9-6 \cdot 1)\end{array}$ & $\begin{array}{l}5 \cdot 7 \pm 0 \cdot 3 \\
(4 \cdot 9-6 \cdot 3)\end{array}$ & $\begin{array}{l}5 \cdot 4 \pm 0 \cdot 1 \\
(5 \cdot 3-5 \cdot 6)\end{array}$ & $\begin{array}{l}6 \cdot 1 \pm 0 \cdot 4 \\
(5 \cdot 4-7 \cdot 0)\end{array}$ & $\begin{array}{l}6 \cdot 1 \pm 0 \cdot 3 \\
(5 \cdot 9-6 \cdot 5)\end{array}$ & $\begin{array}{l}6 \cdot 3 \pm 0 \cdot 2 \\
(6 \cdot 2-6 \cdot 7)\end{array}$ \\
\hline MHSTL & $\begin{array}{l}2 \cdot 1 \pm 0 \cdot 1 \\
(1 \cdot 9-2 \cdot 3)\end{array}$ & $\begin{array}{l}2 \cdot 1 \pm 0 \cdot 2 \\
(1 \cdot 9-2 \cdot 5)\end{array}$ & $\begin{array}{l}2 \cdot 1 \pm 0 \cdot 2 \\
(1 \cdot 8-2 \cdot 3)\end{array}$ & $\begin{array}{l}2 \cdot 3 \pm 0 \cdot 2 \\
(1 \cdot 8-2 \cdot 5)\end{array}$ & $\begin{array}{l}2 \cdot 0 \pm 0 \cdot 1 \\
(1 \cdot 8-2 \cdot 3)\end{array}$ & $\begin{array}{l}2 \cdot 0 \pm 0 \cdot 2 \\
(1 \cdot 7-2 \cdot 8)\end{array}$ & $\begin{array}{l}2 \cdot 0 \pm 0 \cdot 1 \\
(1 \cdot 9-2 \cdot 2)\end{array}$ & $\begin{array}{l}2 \cdot 2 \pm 0 \cdot 2 \\
(1 \cdot 9-2 \cdot 5)\end{array}$ & $\begin{array}{l}2 \cdot 1 \pm 0 \cdot 1 \\
(1 \cdot 9-2 \cdot 3)\end{array}$ & $\begin{array}{l}1 \cdot 8 \pm 0 \cdot 2 \\
(1 \cdot 5-2 \cdot 0)\end{array}$ & $\begin{array}{l}1 \cdot 9 \pm 0 \cdot 2 \\
(1 \cdot 7-2 \cdot 1)\end{array}$ & $\begin{array}{l}2 \cdot 1 \pm 0 \cdot 2 \\
(1 \cdot 9-2 \cdot 3)\end{array}$ \\
\hline MHSD & $\begin{array}{l}5 \cdot 8 \pm 0 \cdot 7 \\
(3 \cdot 9-6 \cdot 4)\end{array}$ & $\begin{array}{l}6 \cdot 3 \pm 0 \cdot 3 \\
(5 \cdot 7-6 \cdot 9)\end{array}$ & $\begin{array}{l}6 \cdot 2 \pm 0 \cdot 3 \\
(5 \cdot 7-6 \cdot 7)\end{array}$ & $\begin{array}{l}6 \cdot 0 \pm 0 \cdot 3 \\
(5 \cdot 1-6 \cdot 5)\end{array}$ & $\begin{array}{l}6 \cdot 0 \pm 0 \cdot 2 \\
(5 \cdot 3-6 \cdot 3)\end{array}$ & $\begin{array}{l}6 \cdot 1 \pm 0 \cdot 3 \\
(5 \cdot 6-6 \cdot 7)\end{array}$ & $\begin{array}{l}6 \cdot 4 \pm 0 \cdot 3 \\
(5 \cdot 5-6 \cdot 8)\end{array}$ & $\begin{array}{l}6 \cdot 2 \pm 0 \cdot 2 \\
(5 \cdot 7-6 \cdot 7)\end{array}$ & $\begin{array}{l}6 \cdot 1 \pm 0 \cdot 2 \\
(5 \cdot 8-6 \cdot 5)\end{array}$ & $\begin{array}{l}5 \cdot 3 \pm 0 \cdot 3 \\
(4 \cdot 5-6 \cdot 6)\end{array}$ & $\begin{array}{l}5 \cdot 3 \pm 0 \cdot 2 \\
(5 \cdot 0-5 \cdot 6)\end{array}$ & $\begin{array}{l}5 \cdot 1 \pm 0 \cdot 3 \\
(4 \cdot 9-5 \cdot 4)\end{array}$ \\
\hline MHAD & $\begin{array}{l}6 \cdot 06 \pm 0 \cdot 5 \\
(4 \cdot 7-6 \cdot 4)\end{array}$ & $\begin{array}{l}6 \cdot 4 \pm 0 \cdot 4 \\
(5 \cdot 8-7 \cdot 0)\end{array}$ & $\begin{array}{l}6 \cdot 3 \pm 0 \cdot 3 \\
(5 \cdot 8-6 \cdot 7)\end{array}$ & $\begin{array}{l}6 \cdot 4 \pm 0 \cdot 2 \\
(5 \cdot 7-6 \cdot 9)\end{array}$ & $\begin{array}{l}6 \cdot 1 \pm 0 \cdot 1) \\
(5 \cdot 9-6 \cdot 2\end{array}$ & $\begin{array}{l}6 \cdot 4 \pm 0 \cdot 2 \\
(6 \cdot 1-7 \cdot 2)\end{array}$ & $\begin{array}{l}7 \cdot 0 \pm 0 \cdot 2 \\
(6 \cdot 4-7 \cdot 4)\end{array}$ & $\begin{array}{l}7 \cdot 0 \pm 0 \cdot 2 \\
(6 \cdot 3-7 \cdot 3)\end{array}$ & $\begin{array}{l}6 \cdot 7 \pm 0 \cdot 3 \\
(6 \cdot 0-7 \cdot 1)\end{array}$ & $\begin{array}{l}6 \cdot 9 \pm 0 \cdot 2 \\
(6 \cdot 5-7 \cdot 3)\end{array}$ & $\begin{array}{l}7 \cdot 0 \pm 0 \cdot 8 \\
(5 \cdot 8-7 \cdot 9)\end{array}$ & $\begin{array}{l}7 \cdot 7 \pm 0 \cdot 4 \\
(7 \cdot 2-8 \cdot 2)\end{array}$ \\
\hline МНIH & $\begin{array}{l}0 \cdot 7 \pm 0 \cdot 1 \\
(0 \cdot 6-0 \cdot 8)\end{array}$ & $\begin{array}{l}0 \cdot 7 \pm 0 \cdot 1 \\
(0 \cdot 5-0 \cdot 9)\end{array}$ & $\begin{array}{l}0 \cdot 7 \pm 0 \cdot 1 \\
(0 \cdot 4-1 \cdot 0)\end{array}$ & $\begin{array}{l}0 \cdot 8 \pm 0 \cdot 1 \\
(0 \cdot 6-1 \cdot 0)\end{array}$ & $\begin{array}{l}0 \cdot 7 \pm 0 \cdot 1 \\
(0 \cdot 6-0 \cdot 1)\end{array}$ & $\begin{array}{l}0 \cdot 6 \pm 0 \cdot 1 \\
(0 \cdot 4-0 \cdot 9)\end{array}$ & $\begin{array}{l}1 \cdot 0 \pm 0 \cdot 1 \\
(0 \cdot 7-1 \cdot 2)\end{array}$ & $\begin{array}{l}1 \cdot 0 \pm 0 \cdot 1 \\
(0 \cdot 8-1 \cdot 2)\end{array}$ & $\begin{array}{l}0 \cdot 8 \pm 0 \cdot 1 \\
(0 \cdot 6-1 \cdot 0)\end{array}$ & $\begin{array}{l}0 \cdot 9 \pm 0 \cdot 1 \\
(0 \cdot 6-1 \cdot 1)\end{array}$ & $\begin{array}{l}0 \cdot 5 \pm 0 \cdot 2 \\
(0 \cdot 2-0 \cdot 7)\end{array}$ & $\begin{array}{l}0 \cdot 7 \pm 0 \cdot 2 \\
(0 \cdot 5-0 \cdot 9)\end{array}$ \\
\hline \multicolumn{13}{|l|}{ Hamulus } \\
\hline & $\begin{array}{l}11 \cdot 3 \pm 0 \cdot 6 \\
(10 \cdot 2-12 \cdot 4)\end{array}$ & $\begin{array}{l}11 \cdot 7 \pm 0 \cdot 7 \\
(10 \cdot 4-13 \cdot 3)\end{array}$ & $\begin{array}{l}11 \cdot 3 \pm 0 \cdot 5 \\
(10 \cdot 5-12 \cdot 1)\end{array}$ & $\begin{array}{l}11 \cdot 8 \pm 0 \cdot 5 \\
(11 \cdot 0-12 \cdot 7)\end{array}$ & $\begin{array}{l}11 \cdot 6 \pm 0 \cdot 4 \\
(11 \cdot 0-12 \cdot 6)\end{array}$ & $\begin{array}{l}12 \cdot 1 \pm 0 \cdot 8 \\
(10 \cdot 1-13 \cdot 7)\end{array}$ & $\begin{array}{l}14 \cdot 0 \pm 0 \cdot 7 \\
(12 \cdot 7-15 \cdot 1)\end{array}$ & $\begin{array}{l}13 \cdot 9 \pm 0 \cdot 7 \\
(12 \cdot 6-15 \cdot 4)\end{array}$ & $\begin{array}{l}11 \cdot 4 \pm 0 \cdot 5 \\
(10 \cdot 7-12 \cdot 6)\end{array}$ & $\begin{array}{l}12 \cdot 8 \pm 0 \cdot 6 \\
(11 \cdot 4-13 \cdot 7)\end{array}$ & $\begin{array}{l}9 \cdot 9 \pm 0 \cdot 8 \\
(9 \cdot 0-10 \cdot 9)\end{array}$ & $\begin{array}{l}12 \cdot 6 \pm 0 \cdot 7 \\
(12 \cdot 0-13 \cdot 3)\end{array}$ \\
\hline HAD & $\begin{array}{l}24 \cdot 9 \pm 1 \cdot 4 \\
(22 \cdot 6-26 \cdot 7)\end{array}$ & $\begin{array}{l}24 \cdot 1 \pm 1 \cdot 2 \\
(22 \cdot 1-26 \cdot 7)\end{array}$ & $\begin{array}{l}25 \cdot 3 \pm 1 \cdot 8 \\
(21 \cdot 0-28 \cdot 2)\end{array}$ & $\begin{array}{l}26 \cdot 4 \pm 1 \cdot 2 \\
(24 \cdot 0-28 \cdot 4)\end{array}$ & $\begin{array}{l}24 \cdot 0 \pm 1 \cdot 2 \\
(20 \cdot 4-25 \cdot 2)\end{array}$ & $\begin{array}{l}24 \cdot 3 \pm 2 \cdot 9 \\
(20 \cdot 7-32 \cdot 9)\end{array}$ & $\begin{array}{l}28 \cdot 2 \pm 2 \cdot 4 \\
(22 \cdot 1-33 \cdot 9)\end{array}$ & $\begin{array}{l}27 \cdot 3 \pm 2 \cdot 0 \\
(24 \cdot 5-32 \cdot 3)\end{array}$ & $\begin{array}{l}21 \cdot 7 \pm 1 \cdot 8 \\
(17 \cdot 6-24 \cdot 3)\end{array}$ & $\begin{array}{l}26 \cdot 8 \pm 0,8 \\
(25 \cdot 7-28 \cdot 8)\end{array}$ & $\begin{array}{l}22 \cdot 0 \pm 3 \cdot 1 \\
(18 \cdot 3-26 \cdot 9)\end{array}$ & $\begin{array}{l}28 \cdot 1 \pm 1 \cdot 5 \\
(26 \cdot 1-29 \cdot 5)\end{array}$ \\
\hline HPL & $\begin{array}{l}35 \cdot 3 \pm 1 \cdot 5 \\
(32 \cdot 2-37 \cdot 1)\end{array}$ & $\begin{array}{l}35 \cdot 6 \pm 1 \cdot 1 \\
(33 \cdot 5-37 \cdot 8)\end{array}$ & $\begin{array}{l}34 \cdot 4 \pm 0 \cdot 8 \\
(33 \cdot 4-35 \cdot 7)\end{array}$ & $\begin{array}{l}36 \cdot 1 \pm 1 \cdot 1 \\
(33 \cdot 3-37 \cdot 9)\end{array}$ & $\begin{array}{l}37 \cdot 5 \pm 1 \cdot 0 \\
(36 \cdot 0-39 \cdot 7)\end{array}$ & $\begin{array}{l}39 \cdot 3 \pm 1 \cdot 0 \\
(36 \cdot 7-41 \cdot 4)\end{array}$ & $\begin{array}{l}40 \cdot 3 \pm 0 \cdot 9 \\
(37 \cdot 8-41 \cdot 7)\end{array}$ & $\begin{array}{l}38 \cdot 4 \pm 0 \cdot 8 \\
(37 \cdot 1-39 \cdot 7)\end{array}$ & $\begin{array}{l}35 \cdot 5 \pm 1 \cdot 3 \\
(31 \cdot 6-37 \cdot 1)\end{array}$ & $\begin{array}{l}39 \cdot 5 \pm 1 \cdot 2 \\
(36 \cdot 6-41 \cdot 3)\end{array}$ & $\begin{array}{l}35 \cdot 5 \pm 1 \cdot 4 \\
(34 \cdot 6-37 \cdot 9)\end{array}$ & $\begin{array}{l}39 \cdot 2 \pm 1 \cdot 3 \\
(37 \cdot 8-40 \cdot 9)\end{array}$ \\
\hline HDSW & $\begin{array}{l}6 \cdot 5 \pm 0 \cdot 6 \\
(5 \cdot 5-7 \cdot 9)\end{array}$ & $\begin{array}{l}6 \cdot 3 \pm 0 \cdot 5 \\
(5 \cdot 4-7 \cdot 2)\end{array}$ & $\begin{array}{l}6 \cdot 6 \pm 0 \cdot 5 \\
(5 \cdot 8-7 \cdot 3)\end{array}$ & $\begin{array}{l}6 \cdot 7 \pm 0 \cdot 3 \\
(5 \cdot 8-7 \cdot 3)\end{array}$ & $\begin{array}{l}6 \cdot 8 \pm 0 \cdot 3 \\
(5 \cdot 9-7 \cdot 2)\end{array}$ & $\begin{array}{l}7 \cdot 6 \pm 0 \cdot 7 \\
(6 \cdot 8-9 \cdot 3)\end{array}$ & $\begin{array}{l}7 \cdot 8 \pm 0 \cdot 9 \\
(6 \cdot 8-10 \cdot 7)\end{array}$ & $\begin{array}{l}7 \cdot 9 \pm 0 \cdot 4 \\
(7 \cdot 4-8 \cdot 7)\end{array}$ & $\begin{array}{l}7 \cdot 3 \pm 0 \cdot 2 \\
(6 \cdot 9-7 \cdot 7)\end{array}$ & $\begin{array}{l}8 \cdot 3 \pm 0 \cdot 6 \\
(7 \cdot 2-9 \cdot 3)\end{array}$ & $\begin{array}{l}6 \cdot 0 \pm 0 \cdot 4 \\
(5 \cdot 5-6 \cdot 5)\end{array}$ & $\begin{array}{l}7 \cdot 1 \pm 0 \cdot 2 \\
(6 \cdot 7-7 \cdot 3)\end{array}$ \\
\hline HIA & $\begin{array}{l}43 \cdot 0 \pm 2 \cdot 0 \\
(39 \cdot 8-45 \cdot 8)\end{array}$ & $\begin{array}{l}42 \cdot 0 \pm 1 \cdot 8 \\
(39 \cdot 1-44 \cdot 8)\end{array}$ & $\begin{array}{l}44 \cdot 0 \pm 3 \cdot 0 \\
(38 \cdot 7-48 \cdot 2)\end{array}$ & $\begin{array}{l}45 \cdot 7 \pm 2 \cdot 1 \\
(41 \cdot 4-49 \cdot 7)\end{array}$ & $\begin{array}{l}39 \cdot 3 \pm 2 \cdot 3 \\
(33 \cdot 3-42 \cdot 5)\end{array}$ & $\begin{array}{l}39 \cdot 0 \pm 5 \cdot 1 \\
(33 \cdot 4-55 \cdot 1)\end{array}$ & $\begin{array}{l}42 \cdot 3 \pm 3 \cdot 0 \\
(37 \cdot 1-50 \cdot 9)\end{array}$ & $\begin{array}{l}43 \cdot 1 \pm 2 \cdot 5 \\
(39 \cdot 4-47 \cdot 1)\end{array}$ & $\begin{array}{l}37 \cdot 8 \pm 2 \cdot 8 \\
(31 \cdot 0-42 \cdot 1)\end{array}$ & $\begin{array}{l}41 \cdot 8 \pm 1 \cdot 3 \\
(39 \cdot 8-43 \cdot 9)\end{array}$ & $\begin{array}{l}43 \cdot 3 \pm 8 \cdot 8 \\
(33 \cdot 1-61 \cdot 5)\end{array}$ & $\begin{array}{l}42 \cdot 1 \pm 2 \cdot 3 \\
(40 \cdot 6-45 \cdot 4)\end{array}$ \\
\hline HICL & $\begin{array}{l}4 \cdot 6 \pm 0 \cdot 8 \\
(3 \cdot 8-6 \cdot 6)\end{array}$ & $\begin{array}{l}5 \cdot 3 \pm 0 \cdot 9 \\
(3 \cdot 5-7 \cdot 4)\end{array}$ & $\begin{array}{l}6 \cdot 0 \pm 0 \cdot 6 \\
(4 \cdot 7-6 \cdot 8)\end{array}$ & $\begin{array}{l}5 \cdot 6 \pm 0 \cdot 9 \\
(3 \cdot 7-7 \cdot 6)\end{array}$ & $\begin{array}{l}4 \cdot 3 \pm 0 \cdot 6 \\
(3 \cdot 4-5 \cdot 8)\end{array}$ & $\begin{array}{l}3 \cdot 9 \pm 1 \cdot 0 \\
(1 \cdot 6-6 \cdot 2)\end{array}$ & $\begin{array}{l}5 \cdot 5 \pm 0 \cdot 6 \\
(4 \cdot 4-6 \cdot 5)\end{array}$ & $\begin{array}{l}6 \cdot 6 \pm 1 \cdot 4 \\
(4 \cdot 6-9 \cdot 6)\end{array}$ & $\begin{array}{l}5 \cdot 4 \pm 1 \cdot 0 \\
(3 \cdot 6-7 \cdot 9)\end{array}$ & $\begin{array}{l}6 \cdot 2 \pm 0 \cdot 9 \\
(4 \cdot 6-7 \cdot 4)\end{array}$ & $\begin{array}{l}6 \cdot 5 \pm 1 \cdot 5 \\
(4 \cdot 8-8 \cdot 1)\end{array}$ & $\begin{array}{l}5 \cdot 0 \pm 1 \cdot 7 \\
(3 \cdot 1-6 \cdot 8)\end{array}$ \\
\hline HSL & $\begin{array}{l}43 \cdot 2 \pm 1 \cdot 6 \\
(39 \cdot 40-45 \cdot 3)\end{array}$ & $\begin{array}{l}42 \cdot 8 \pm 1 \cdot 6 \\
(40 \cdot 1-46 \cdot 1)\end{array}$ & $\begin{array}{l}43 \cdot 0 \pm 1 \cdot 7 \\
(40 \cdot 62-46 \cdot 1)\end{array}$ & $\begin{array}{l}44 \cdot 5 \pm 1 \cdot 3 \\
(42 \cdot 2-48 \cdot 0)\end{array}$ & $\begin{array}{l}44 \cdot 4 \pm 1 \cdot 1 \\
(42 \cdot 0-45 \cdot 9)\end{array}$ & $\begin{array}{l}46 \cdot 5 \pm 1 \cdot 3 \\
(44 \cdot 6-49 \cdot 1)\end{array}$ & $\begin{array}{l}51 \cdot 4 \pm 1 \cdot 6 \\
(47 \cdot 2-53 \cdot 7)\end{array}$ & $\begin{array}{l}46 \cdot 8 \pm 1 \cdot 7 \\
(44 \cdot 0-50 \cdot 4)\end{array}$ & $\begin{array}{l}42 \cdot 4 \pm 1 \cdot 6 \\
(38 \cdot 7-44 \cdot 4)\end{array}$ & $\begin{array}{l}48 \cdot 1 \pm 1 \cdot 1 \\
(46 \cdot 6-50 \cdot 3)\end{array}$ & $\begin{array}{l}42 \cdot 5 \pm 2 \cdot 8 \\
(39 \cdot 9-47 \cdot 0)\end{array}$ & $\begin{array}{l}50 \cdot 0 \pm 3 \cdot 3 \\
(46 \cdot 2-54 \cdot 2)\end{array}$ \\
\hline HRL & $\begin{array}{l}24 \cdot 7 \pm 0 \cdot 8 \\
(23 \cdot 6-25 \cdot 8)\end{array}$ & $\begin{array}{l}23 \cdot 1 \pm 1 \cdot 5 \\
(20 \cdot 5-26 \cdot 3)\end{array}$ & $\begin{array}{l}23 \cdot 5 \pm 1 \cdot 0 \\
(21 \cdot 7-24 \cdot 6)\end{array}$ & $\begin{array}{l}24 \cdot 7 \pm 1 \cdot 6 \\
(20 \cdot 8-27 \cdot 6)\end{array}$ & $\begin{array}{l}27 \cdot 0 \pm 1 \cdot 9 \\
(23 \cdot 4-30 \cdot 7)\end{array}$ & $\begin{array}{l}27 \cdot 5 \pm 1 \cdot 2 \\
(24 \cdot 6-29 \cdot 9)\end{array}$ & $\begin{array}{l}27 \cdot 0 \pm 1 \cdot 2 \\
(24 \cdot 9-29 \cdot 2)\end{array}$ & $\begin{array}{l}26 \cdot 5 \pm 1 \cdot 4 \\
(24 \cdot 9-30 \cdot 1)\end{array}$ & $\begin{array}{l}23 \cdot 2 \pm 1 \cdot 7 \\
(19 \cdot 5-26 \cdot 4)\end{array}$ & $\begin{array}{l}26 \cdot 2 \pm 1 \cdot 1 \\
(24 \cdot 5-28 \cdot 4)\end{array}$ & $\begin{array}{l}22 \cdot 0 \pm 2 \cdot 4 \\
(18 \cdot 0-23 \cdot 7)\end{array}$ & $\begin{array}{l}27 \cdot 7 \pm 1 \cdot 5 \\
(25 \cdot 8-29 \cdot 3)\end{array}$ \\
\hline HTL & $\begin{array}{l}70 \cdot 6 \pm 2 \cdot 8 \\
(64 \cdot 0-74 \cdot 2)\end{array}$ & $\begin{array}{l}68 \cdot 0 \pm 2 \cdot 2 \\
(63 \cdot 2-72 \cdot 1)\end{array}$ & $\begin{array}{l}70 \cdot 1 \pm 1 \cdot 7 \\
(67 \cdot 7-72 \cdot 9)\end{array}$ & $\begin{array}{l}72 \cdot 7 \pm 1 \cdot 8 \\
(68 \cdot 9-75 \cdot 2)\end{array}$ & $\begin{array}{l}72 \cdot 4 \pm 2 \cdot 7 \\
(66 \cdot 3-75 \cdot 2)\end{array}$ & $\begin{array}{l}75 \cdot 9 \pm 1 \cdot 8 \\
(72 \cdot 5-79 \cdot 4)\end{array}$ & $\begin{array}{l}82 \cdot 7 \pm 2 \cdot 3 \\
(77 \cdot 3-85 \cdot 6)\end{array}$ & $\begin{array}{l}78 \cdot 5 \pm 2 \cdot 5 \\
(74 \cdot 6-82 \cdot 8)\end{array}$ & $\begin{array}{l}69 \cdot 7 \pm 2 \cdot 1 \\
(66 \cdot 6-73 \cdot 1)\end{array}$ & $\begin{array}{l}80 \cdot 0 \pm 1 \cdot 8 \\
(75 \cdot 9-82 \cdot 7)\end{array}$ & $\begin{array}{l}69 \cdot 8 \pm 3 \cdot 5 \\
(64 \cdot 0-73 \cdot 1)\end{array}$ & $\begin{array}{l}82 \cdot 1 \pm 2 \cdot 1) \\
(79 \cdot 8-84 \cdot 1\end{array}$ \\
\hline
\end{tabular}




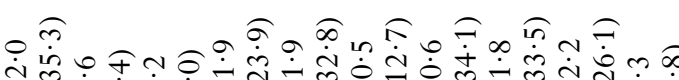

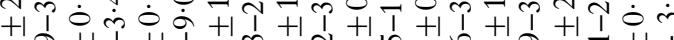

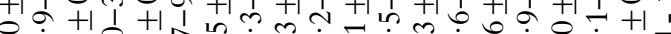

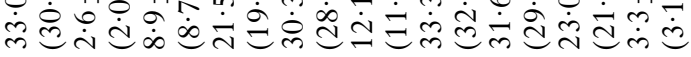

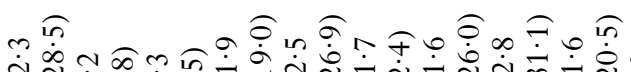

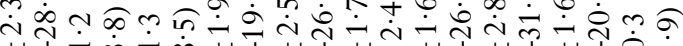

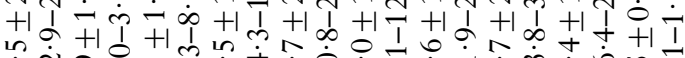

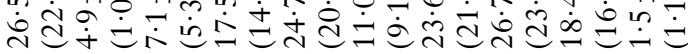

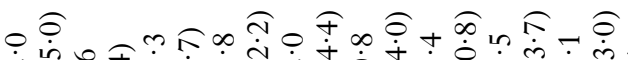
m $+1++\tau+1+1\}+1\}$

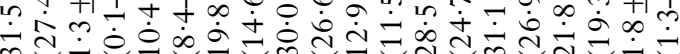

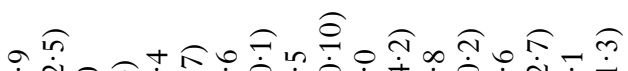

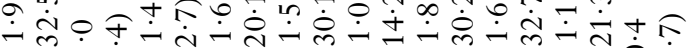
+1

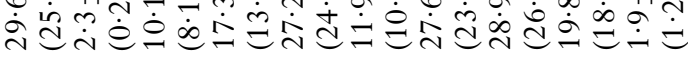

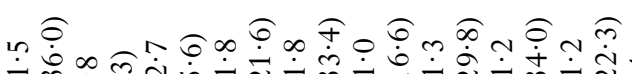
तो

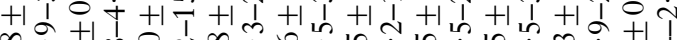

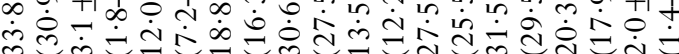

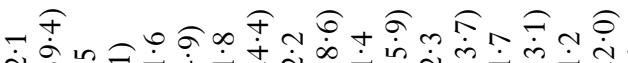
نे

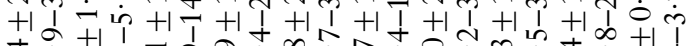

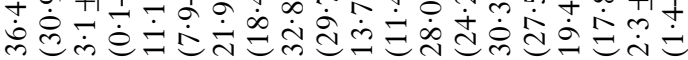

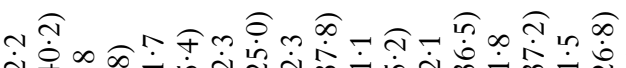

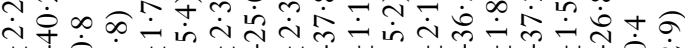

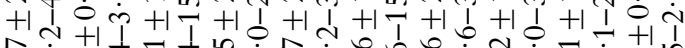

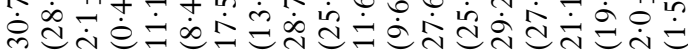

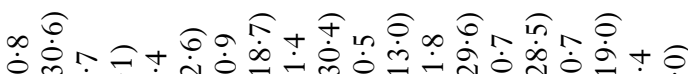

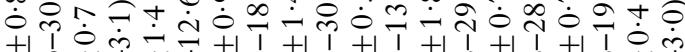

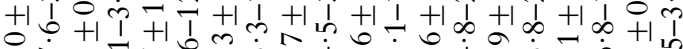

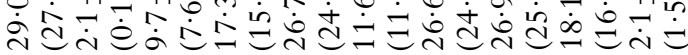
r

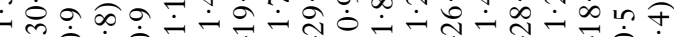

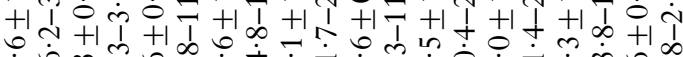

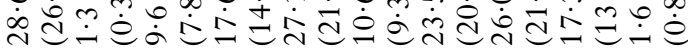

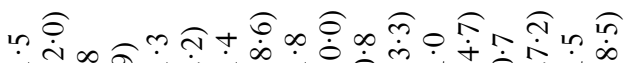

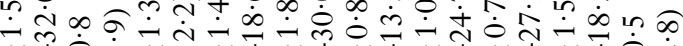

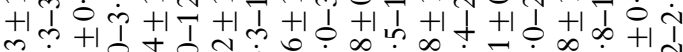

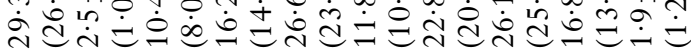

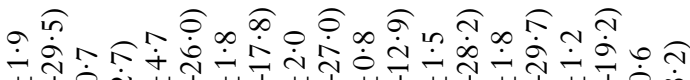

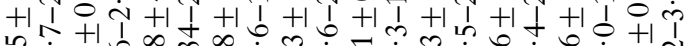

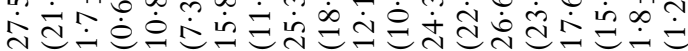

a

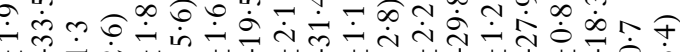

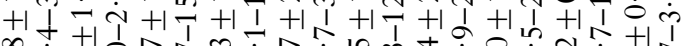

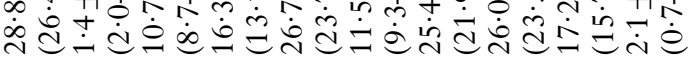

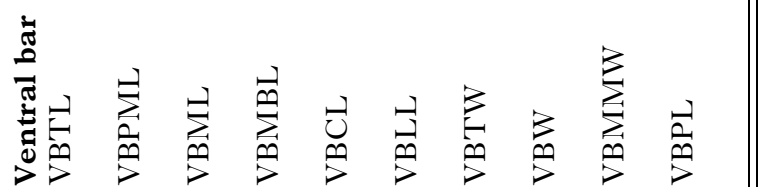

G. salaris populations, are slightly higher. One exception is the population from Drammenselva, with which gyrodactylids from Bullaren share the same mitochondrial haplotype. The most striking difference when analysing Mahalanobis distances from PC2-9 is that $G$. thymalli from Hnilec resembles more the $G$. salaris populations (less Pålsbufjord) than the other G. thymalli populations.

\section{DISCUSSION}

In the current paper, we analysed the morphological differentiation of 10 populations of $G$. salaris and $G$. thymalli that have mitochondrial haplotypes belonging to 6 well-supported haplogroups (Hansen et al. 2006). We noticed a substantial interpopulation and intrapopulation variation in hook morphometry. Such variation can either be due to phenotypic plasticity in response to varying environmental factors, or it could reflect true genotypic differentiation (or a combination of both). Given the high level of mitochondrial DNA differentiation in the Gyrodactylus populations, morphometrical variations may be attributed to genotypic variation due to adaptation to local micro- and macroenvironmental constraints. However, if caused by phenotypic plasticity, the observed variation is expected to blur and weaken any gentotypic and phylogenetic signal in the morphometric analyses.

\section{Type-material and species assignment}

The samples in the present study were assigned to species a priori based on host species: the samples from Drammenselva, Skibotnelva, Rauma and Göta älv were assigned to G. salaris, and the samples from the Hnilec, Lesjaskogsvatn, Trysilelva and Rena were considered $G$. thymalli. The Bullaren and Pålsbufjord populations were sampled from rainbow trout and Arctic charr, respectively. Both parasite populations do, however, share identical mitochondrial cox1 sequences with, for example, the Drammenselva population and have thus been regarded as $G$. salaris (see Hansen et al. 2003; Robertsen et al. 2007). Variation along the first principal component was continuous with no immediately apparent groupings. A more detailed analysis, however, revealed 2 separate groups but with the population from Pålsbufjord in between. The 2 groups included (i) the G. salaris typematerial, the a priori assigned $G$. salaris populations, Bullaren, and the Trysilelva population parasitizing grayling, and (ii) the G. thymalli type-material, and the $a$ priori assigned $G$. thymalli populations (except Trysilelva). The results from the k-means clustering were consistent with the PCA: the Bullaren population most closely resembled the ' $G$. salaris group' 
Table 3. Individual classifications based on $\mathrm{k}$-means clustering into 2 and 3 groups of the morphometric measurements from the 10 populations of Gyrodactylus analysed as well as the G. salaris and G. thymalli type-material

(Number of specimens classified into respective groups is given. * - Rainbow trout. ** - Arctic charr. *** - Grayling. Others hosted by Atlantic salmon.)

\begin{tabular}{|c|c|c|c|c|c|}
\hline & \multicolumn{2}{|l|}{2 groups } & \multicolumn{3}{|l|}{3 groups } \\
\hline & Group 1 & Group 2 & Group 1 & Group 2 & Group 3 \\
\hline G. salaris paralectotypes & 5 & 0 & 5 & 0 & 0 \\
\hline G. thymalli syntypes & 0 & 4 & 0 & 4 & 0 \\
\hline Drammenselva & 12 & 0 & 10 & 0 & 2 \\
\hline Skibotnelva & 14 & 0 & 13 & 0 & 1 \\
\hline Rauma & 12 & 0 & 11 & 0 & 1 \\
\hline Göta älv & 17 & 0 & 12 & 0 & 5 \\
\hline Bullaren* & 14 & 0 & 3 & 0 & 11 \\
\hline Pålsbufjord*** & 15 & 15 & 0 & 4 & 26 \\
\hline Trysilelva**** & 15 & 0 & 12 & 0 & 3 \\
\hline Lesjaskogsvatn**** & 1 & 13 & 0 & 8 & 6 \\
\hline Rena*** & 0 & 18 & 0 & 13 & 5 \\
\hline Hnilec**** & 0 & 15 & 0 & 15 & 0 \\
\hline
\end{tabular}

whereas the Pålsbufjord population represented an intermediate group positioned between the G. salaris and $G$. thymalli groups. The grayling parasites from Trysilelva resembled gyrodactylids collected from Atlantic salmon. The remaining populations of Gyrodactylus resembled the type-material representing their respective species in accordance with the $a$ priori species designations. From a taxonomic viewpoint, these morphometric data confirm the species status of the a priori assigned populations except for the Trysilelva population.

\section{Intra- and interspecific variation}

The Gyrodactylus populations included in this study could be distinguished from each other by morphometry; all populations had significantly different multidimensional means. It is noteworthy that intraspecific pairwise Mahalanobis distances were lower among $G$. salaris parasitizing salmon than among the populations of $G$. thymalli parasitizing grayling, this also holds true when excluding the Trysilelva population from the comparison (Mann-Whitney $\mathrm{U}$ test: $P=0 \cdot 03$ ).

When PC1, which is usually considered the sizeaxis (Jolicoeur and Mosiman, 1960; Reyment et al. 1984), was excluded from the analyses, the Mahalanobis distances indicated that $G$. thymalli specimens from Trysilelva were different from all $G$. salaris specimens, whereas the Hnilec and Lesjaskogsvatn populations resembled the $G$. salaris specimens. This pattern was, however, not fully congruent with the Hotelling's pairwise comparisons when relaxing the statistical power; the Trysilelva population was not significantly different from the $G$. salaris populations when including size. It is noteworthy that for a size-measure such as hamulus total length (HTL) the specimens from Hnilec, with a water temperature of $12{ }^{\circ} \mathrm{C}$ at the time of sampling, were the biggest (mean $83 \mu \mathrm{m}$ ), whereas the specimens from Skibotnelva, which were collected at $3{ }^{\circ} \mathrm{C}$, were the smallest (mean $68 \mu \mathrm{m}$ ). If one assumes that these size differences are due to ambient temperature affecting otherwise undistinguishable traits, the observed pattern would be opposite of previous publications stressing that cold conditions will lead to larger hooks due to extended development-time (suggested by Kulemina, 1977; Mo, 1991 a). Whether or not the observed variation is within the range of phenotypic plasticity of size and shape or represents genetic differentiation, remains unknown. For example, it has been shown from laboratory experiments that Gyrodactylus exhibit differences in developmental time and fecundity on different hosts (Cable et al. 2000). Since the opisthaptoral hard parts do not grow after birth (Kulemina, 1977), the particular parasite strain - host species relationship may be expected to constitute a significant factor for variation in size and shape given growth is allometric, or for size only if growth is isometric.

\section{Taxonomic implications}

One of the alternative taxonomic scenarios proposed by Hansen et al. (2003) is that G. salaris and $G$. thymalli may represent a complex of more than 2 sibling species. The fact that the samples from Bullaren and Pålsbufjorden grouped together separately from the Atlantic salmon and grayling 

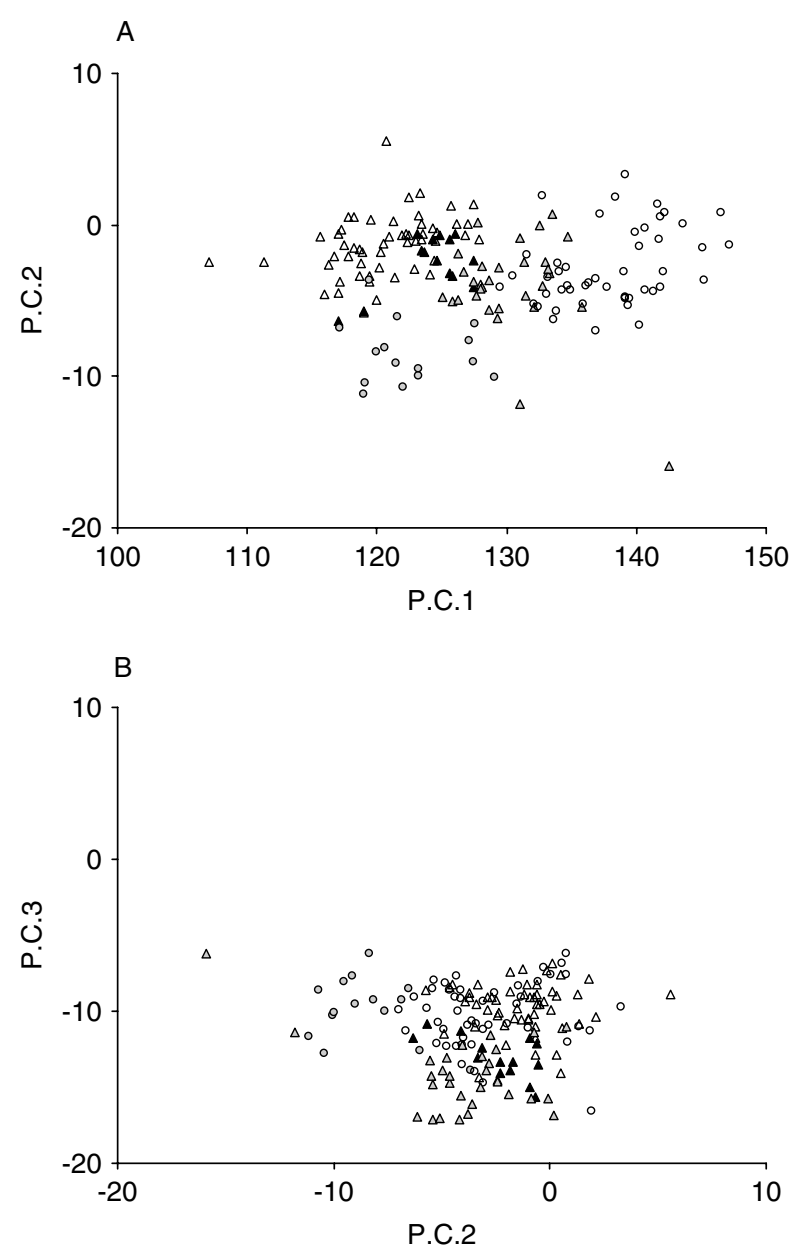

Fig. 2. Principal component analyses of 27 morphometric variables taken from10 populations of Gyrodactylus salaris and G. thymalli. Open triangles $-G$. salaris (hosted by Atlantic salmon) from Drammenselva, Skibotnelva, Rauma, and Göta älv, as well as the $G$. salaris type-material. Black triangles $-G$. salaris from Lake Bullaren rainbow trout. Shaded triangles $-G$. salaris from Lake Pålsbufjord Arctic charr. Open circles $-G$. thymalli (hosted by grayling) from Hnilec, Lesjaskogsvatn and Rena, as well as the G. thymalli type-material. Shaded circles $-G$. thymalli from River Trysilelva grayling. (A) A distribution map of each Gyrodactylus population with the first principal component axis (PC1) plotted against the second (PC2).

(B) The distribution of each Gyrodactylus population when the second principal component axis (PC2) is plotted against the third (PC3).

parasites might bring indications of such a scenario, particularly since they share a common cox1 haplotype (Robertsen et al. 2007). However, these 2 populations also share a common $\operatorname{cox} 1$ haplotype with the G. salaris from River Drammenselva (Hansen et al. 2003), a population that they did not group together with in the present analyses. The present analyses may, in this matter, be biased due to the selection of the populations, and an extended sampling including specimens from Finland and
Russia (clades III and IV according to Meinilä et al. 2004) may alter the results. The rejection of the hypothesis of equal multi-dimensional means and the high level of correct assignments for specimens from all studied populations in the classification tests may, on the other hand, at least not contradict the hypothesis of $G$. salaris and $G$. thymalli being a complex of more than 2 sibling species. However, the present morphometrical differentiation as presented by the PCA analysis is not suitably sufficient to allow for a clear delineation on a subspecies level and does not, therefore, provide strong support for this hypothesis. According to the sibling species complex hypothesis (Hansen et al. 2003), one would expect minor differentiation of the $G$. salaris populations from Skibotnelva and Rauma representing the same mitochondrial haplogroup and both parasitizing Atlantic salmon. However, the G. salaris populations from these 2 rivers are as differentiated as any other populations under study. When taking into account that some of the morphological characters of the opisthaptoral hard parts in Gyrodactylus are also influenced by temperature (see Malmberg, 1970; Mo, $1991 a, b, c$; Dmitrieva and Dimitrov, 2002; Davidova et al. 2005), and probably also by host species (Dmitrieva and Dimitrov, 2002; Huyse and Volkaert, 2002; unpublished findings), we are tempted to conclude that the observed morphometric variation in the measured characters for $G$. salaris and $G$. thymalli does not indicate more than 2 sibling species.

In conclusion, our morphometric data did not clearly support the delineation of the $G$. salaris/ $G$. thymalli species complex into 2 or more groups. Our study also illustrates that there is an urgent need for more detailed knowledge on the environmental factors influencing the phenotype of Gyrodactylus populations. At present, by far most of the 409 described gyrodactylid species (Harris et al. 2004) are 'morphological species', as they are described without including molecular data. More information on the environmental impact on gyrodactylid morphology is, therefore, needed for the interpretation of the taxonomic significance of the morphometrical differences observed between Gyrodactylus populations in general. With particular reference to G. salaris and G. thymalli, our results indicate that the species determination of gyrodactylid species taken from wild populations of fish, when based solely on morphometrics, is more complicated and problematic than initially thought.

This work was supported by the Norwegian Research Council 'Wild Salmon Programme' (Project no. 145861/ 720 ) and the National Centre for Biosystematics (Project no. 146515/420, co-funded by the NRC and the NHM, University of Oslo, Norway). We thank G. Malmberg and V. Dudinak for providing access to and additional information regarding the $G$. salaris and $G$. thymalli type material, respectively; V. Hanzelova for providing 
Table 4. Hotelling's pairwise post-hoc comparisons of PC1-PC9 (below the diagonal) and PC2-PC9 (above the diagonal) for 10 populations of Gyrodactylus salaris and $G$. thymalli, infecting four different host species (see text)

$(\dagger-$ non-significant results $(P \geqslant 0 \cdot 05)$ * - Rainbow trout. ** - Arctic charr. *** - Grayling. Others hosted by Atlantic salmon.)

\begin{tabular}{|c|c|c|c|c|c|c|c|c|c|c|}
\hline & Drammenselva & Skibotnelva & Rauma & Göta älv & Bullaren* & Pålsbufjord*** & Trysilelva**** & Lesjaskogsvatn**** & Rena**** & Hnilec $* * *$ \\
\hline Drammenselva & - & $1 \cdot 56^{\dagger}$ & $<0 \cdot 01$ & $0 \cdot 06^{\dagger}$ & $0 \cdot 10$ & $<0.01$ & $0 \cdot 29^{\dagger}$ & $<0 \cdot 01$ & $<0.01$ & $<0 \cdot 01$ \\
\hline Skibotnelva & $2 \cdot 20^{\dagger}$ & - & $0 \cdot 47^{\dagger}$ & $<0 \cdot 01$ & $<0 \cdot 01$ & $<0.01$ & $0 \cdot 05^{\dagger}$ & $0.08^{\dagger}$ & $0 \cdot 01$ & $<0.01$ \\
\hline Rauma & $0 \cdot 01$ & $1 \cdot 02^{\dagger}$ & - & $<0.01$ & $<0.01$ & $<0.01$ & $1 \cdot 03^{\dagger}$ & $0 \cdot 78^{\dagger}$ & $<0 \cdot 01$ & $<0.01$ \\
\hline Göta älv & $0.08^{\dagger}$ & $<0 \cdot 01$ & 0.01 & - & $<0.01$ & $<0.01$ & $<0 \cdot 01$ & $<0 \cdot 01$ & $<0.01$ & $<0.01$ \\
\hline Bullaren & $0 \cdot 06^{\dagger}$ & $<0 \cdot 01$ & $<0 \cdot 01$ & $<0 \cdot 01$ & - & $<0 \cdot 01$ & $<0 \cdot 01$ & $<0 \cdot 01$ & $<0 \cdot 01$ & $<0 \cdot 01$ \\
\hline Pålsbufjord & $<0 \cdot 01$ & $<0 \cdot 01$ & $<0.01$ & $<0 \cdot 01$ & $<0 \cdot 01$ & - & $<0 \cdot 01$ & $<0 \cdot 01$ & $<0 \cdot 01$ & $<0 \cdot 01$ \\
\hline Trysilelva & $<0 \cdot 01$ & $<0 \cdot 01$ & $<0.01$ & $<0.01$ & $<0 \cdot 01$ & $<0 \cdot 01$ & - & $<0 \cdot 01$ & $<0 \cdot 01$ & $<0 \cdot 01$ \\
\hline Lesjaskogsvatn & $<0 \cdot 01$ & $<0 \cdot 01$ & $<0 \cdot 01$ & $<0 \cdot 01$ & $<0 \cdot 01$ & $<0 \cdot 01$ & $<0 \cdot 01$ & - & $<0 \cdot 01$ & $<0 \cdot 01$ \\
\hline Rena & $<0.01$ & 0.02 & $<0.01$ & $<0.01$ & $<0.01$ & $<0.01$ & $<0.01$ & $<0.01$ & - & $<0.01$ \\
\hline Hnilec & $<0 \cdot 01$ & $<0 \cdot 01$ & $<0 \cdot 01$ & $<0 \cdot 01$ & $<0 \cdot 01$ & $<0 \cdot 01$ & $<0 \cdot 01$ & $<0 \cdot 01$ & $<0 \cdot 01$ & - \\
\hline
\end{tabular}

Table 5. Mahalanobis distances for the principal components PC1-PC9 (above the diagonal) and PC2-PC9 (below the diagonal) for 10 populations of Gyrodactylus salaris and $G$. thymalli, infecting four different host species

(* - Rainbow trout. ** - Arctic charr. *** - Grayling. Others hosted by Atlantic salmon.)

\begin{tabular}{|c|c|c|c|c|c|c|c|c|c|c|}
\hline & Drammenselva & Skibotnelva & Rauma & Göta älv & Bullaren* & Pålsbufjord*** & Trysilelva**** & Lesjaskogsvatn**** & Rena**** & Hnilec**** \\
\hline Drammenselva & - & $6 \cdot 84$ & $11 \cdot 81$ & $11 \cdot 24$ & $6 \cdot 34$ & $24 \cdot 68$ & $24 \cdot 21$ & $49 \cdot 42$ & $54 \cdot 76$ & $67 \cdot 28$ \\
\hline Skibotnelva & $6 \cdot 84$ & - & $6 \cdot 19$ & 8.58 & $14 \cdot 78$ & $28 \cdot 72$ & $11 \cdot 15$ & $39 \cdot 03$ & $45 \cdot 05$ & $68 \cdot 43$ \\
\hline Rauma & $11 \cdot 48$ & $5 \cdot 81$ & - & $7 \cdot 04$ & $23 \cdot 26$ & $40 \cdot 20$ & $20 \cdot 21$ & $30 \cdot 44$ & $49 \cdot 08$ & $56 \cdot 61$ \\
\hline Göta älv & 8.79 & 5.97 & $6 \cdot 06$ & - & $16 \cdot 67$ & $26 \cdot 93$ & $20 \cdot 52$ & $29 \cdot 29$ & $29 \cdot 99$ & $47 \cdot 39$ \\
\hline Bullaren & $4 \cdot 10$ & $12 \cdot 39$ & $22 \cdot 41$ & $16 \cdot 67$ & - & $8 \cdot 19$ & $23 \cdot 22$ & $42 \cdot 79$ & $41 \cdot 67$ & $54 \cdot 15$ \\
\hline Pålsbufjord & $11 \cdot 61$ & $15 \cdot 30$ & $30 \cdot 93$ & $22 \cdot 73$ & $3 \cdot 69$ & - & $25 \cdot 49$ & $33 \cdot 00$ & $25 \cdot 46$ & $44 \cdot 14$ \\
\hline Trysilelva & $22 \cdot 07$ & $8 \cdot 86$ & $19 \cdot 41$ & $20 \cdot 51$ & $23 \cdot 22$ & $20 \cdot 86$ & - & $27 \cdot 82$ & $28 \cdot 77$ & $66 \cdot 66$ \\
\hline Lesjaskogsvatn & $17 \cdot 83$ & $6 \cdot 89$ & 4.94 & $12 \cdot 84$ & $25 \cdot 77$ & $28 \cdot 97$ & $10 \cdot 53$ & - & $14 \cdot 64$ & $22 \cdot 74$ \\
\hline Rena & $18 \cdot 34$ & $8 \cdot 04$ & $19 \cdot 22$ & $10 \cdot 01$ & $21 \cdot 06$ & $19 \cdot 60$ & $7 \cdot 87$ & $14 \cdot 47$ & - & 31.06 \\
\hline Hnilec & $8 \cdot 71$ & $9 \cdot 11$ & $6 \cdot 44$ & $10 \cdot 31$ & $16 \cdot 23$ & $27 \cdot 83$ & $28 \cdot 34$ & $18 \cdot 61$ & $28 \cdot 44$ & - \\
\hline
\end{tabular}


samples of G. thymalli from river Hnilec, Slovakia; H. Hansen, D. Gammelsæter, T. Haugen, L. Karlsson, I. Perä, O. Eide, P. Arnkværn, and T. Olstad for help in collecting material in Scandinavia; H.J. Berg and C. Vollelv for assisting in SEM photography; and $\mathrm{G}$. Robertsen for assisting in the preparation of specimens.

\section{REFERENCES}

Bakke, T. A., Harris, P. D. and Cable, J. (2002). Host specificity dynamics: observations on gyrodactylid monogeneans. International Fournal for Parasitology 32, 281-308. DOI :10.1016/S0020-7519(01)00331-9

Bakke, T. A., Cable, J. and Harris, P. D. (2007). The biology of gyrodactylid monogeneans: the "Russian Doll-killers". Advances in Parasitology 64, 161-376. DOI : 10.1016/S0065-308(06)64003-7

Cable, J., Harris, P. D. and Bakke, T. A. (2000). Population growth of Gyrodactylus salaris (Monogenea) on Norwegian and Baltic Atlantic salmon (Salmo salar) stocks. Parasitology 121, 621-629. DOI:10.1017/ S0031182000006971

Cunningham, C. O. (1997). Species variation within the internal transcribed spacer (ITS) region of Gyrodactylus (Monogenea: Gyrodactylidae) ribosomal RNA genes. Fournal of Parasitology 83, 215-219.

Dávidová, M., Jarkovský, J., Matějusová, I. and Gelnar, M. (2005). Seasonal occourence and metric variability of Gyrodactylus rhodei Žitňan, 1964 (Monogenea, Gyrodactylidae). Parasitology Research 95, 398-405. DOI :10.1007/S00436-005-1311-0

Dmitrieva, E. and Dimitrov, G. (2002). Variabiltiy in the taxonomic characters of Black Sea gyrodactylids (Monogenea). Systematic Parasitology 51, 199-206.

Ergens, R. (1983). Gyrodactylus from Eurasian freshwater Salmonidae and Thymallidae. Folia Parasitologica 30, 15-26.

Hammer, Ø., Harper, D. A. T. and Ryan, P. D. (2001). PAST: Paleontological Statistics Software Package for Education and Data Analysis. Palaeontologia Electronica 4, 9pp.

Hansen, H., Bachmann, L. and Bakke, T. A. (2003). Mitochondrial DNA variation of Gyrodactylus spp. (Monogenea, Gyrodactylidae) populations infecting Atlantic salmon, grayling, and rainbow trout in Norway and Sweden. International Fournal for Parasitology 33, 1471-1478. DOI:10.1016/S0020-7519(03)00200-5.

Hansen, H., Martinsen, L., Bakke, T. A. and Bachmann, L. (2006). The incongruence of nuclear and mitochondrial DNA variation supports conspecificity of the monogenean parasites Gyrodactylus salaris and $G$. thymalli. Parasitology 133, 639-650. DOI:10.1017/ S0031182006000655

Harris, P. D., Cable, J., Tinsley, R. C. and Lazarus, C. M. (1999). Combined ribosomal DNA and morphological analysis of individual gyrodactylid monogeneans. Fournal of Parasitology 85, 188-191.

Harris, P. D., Shinn, A. P., Cable, J. and Bakke, T. A. (2004). Nominal species of the genus Gyrodactylus von Normann 1832 (Monogenea: Gyrodactylidae), with a list of principal host species. Systematic Parasitology 59, 1-27. DOI:10.1023/B:SYPA.0000038447. 52015.e4
Huyse, T. and Volckaert, F. A. M. (2002). Identification of a host-associated species complex using molecular and morphometric analyses, with the description of Gyrodactylus rugiensoides n. sp. (Gyrodactylidae, Monogenea). International Fournal for Parasitology 32, 907-919. DOI :10.1016/S0020-7519(02)00026-7

Johnsen, B. O., Møkkelgjerd, P. I. and Jensen, A. J. (1999). The parasite Gyrodactylus salaris on salmon parr in Norwegian rivers, status report at the beginning of year 2000. NINA Oppdragsmelding 617, 1-129. (In Norwegian.)

Jolicoeur, P. and Mosimann, J. (1960). Size and shape in the painted turtle. A principal component analysis. Growth 24, 339-354.

Jørgensen, T. R., Larsen, T. B., Jørgensen, L. G., Bresciani, J., Kania, P. W. and Buchmann, $K$. (2007). Characterisation of a low pathogenic form of Gyrodactylus salaris from rainbow trout. Diseases of Aquatic Organisms 73, 235-244.

Kulemina, I. V. (1977). Size variability of the adhesive elements in some species of Gyrodactylus. In Investigations of Monogeneans in the USSR (ed. Skarlato O. A.), pp. 38-41. Oxonian Press Pvt. Ltd 1987, New Dehli, India.

Malmberg, G. (1957). Om förekomsten av Gyrodactylus på svenska fiskar. Skrifter utgivna av Södra Sveriges Fiskeriförening, Årsskrift 1956, 19-76. (In Swedish.)

Malmberg, G. (1970). The excretory systems and the marginal hooks as a basis for the systematics of Gyrodactylus (Trematoda, Monogenea). Arkiv für Zoologie 23, 1-235.

McHugh, E. S., Shinn, A. P. and Kay, J. W. (2000). Discrimination of the notifiable pathogen Gyrodactylus salaris from G. thymalli (Monogenea) using statistical classifiers applied to morphometric data. Parasitology 121, 315-323. DOI:10.1017/S0031182099006381

Meinilä, M., Kuusela, J., Ziętara, M. S. and Lumme, J. (2004). Initial steps of speciation by geographic isolation and host switch in salmonid pathogen Gyrodactylus salaris (Monogenea: Gyrodactylidae). International Fournal for Parasitology 34, 515-526. DOI : 10.1016/j.ijpara.2003.12.002

Mo, T. A. (1991 a). Seasonal variations of opisthaptoral hard parts of Gyrodactylus salaris Malmberg, 1957 (Monogenea: Gyrodactylidae) on parr of Atlantic salmon Salmo salar L. in the river Batnfjordselva, Norway. Systematic Parasitology 19, 231-240.

Mo, T. A. (1991 b). Variations of opisthaptoral hard parts of Gyrodactylus salaris Malmberg, 1957 (Monogenea: Gyrodactylidae) on rainbow trout (Oncorhynchus mykiss (Walbaum, 1792)) in a fish farm, with comments on the spreading of the parasite in south-eastern Norway. Systematic Parasitology 20, 1-9.

Mo, T. A. $(1991 c)$. Variations of opisthaptoral hard parts of Gyrodactylus salaris Malmberg, 1957 (Monogenea: Gyrodactylidae) on parr of Atlantic salmon Salmo salar L. in laboratory experiments. Systematic Parasitology 20, 11-19.

Mo, T. A., Norheim, K. and Hellesnes, I. (2004). The surveillance and control programme for Gyrodactylus salaris in Atlantic salmon and rainbow trout in Norway. Norsk Veterincertidsskrift 3, 157-163. (In Norwegian, English summary.) 
Olstad, K., Robertsen, G., Bachmann, L. and Bakke, T. A. (2007). Variation in host preference within Gyrodactylus salaris (Monogenea): an experimental approach. Parasitology 134, 589-597. DOI : $10.1017 / \mathrm{S} 0031182006001715$

Reyment, R. A., Blackith, R. E. and Campell, N. A. (1984). Multivariate Morphometrics, 2nd Edn. Academic Press, London.

Robertsen, G., Hansen, H., Bachmann, L. and Bakke, T. A. (2007). Arctic charr (Salvelinus alpinus) is a suitable host for Gyrodactylus salaris (Monogenea, Gyrodactylidae) in Norway. Parasitology 134, 257-267. DOI : 10.1017/S0031182006001223

Shinn, A. P., Hansen, H., Olstad, K., Bachmann, L. and Bakke, T. A. (2004). The use of morphometric characters to discriminate specimens of laboratoryreared and wild populations of Gyrodactylus salaris and G. thymalli (Monogenea). Folia Parasitologica 51, 239-252.
Soleng, A. and Bakke, T. A. (2001). The susceptibility of grayling, Thymallus thymallus to experimental infections with the monogenean Gyrodactylus salaris. International Fournal for Parasitology 31, 793-797. DOI:10.1016/S0020-7519(01)00188-6

Sterud, E., Mo, T. A., Collins, C. M. and Cunningham, C. O. (2002). The use of host specificity, pathogenicity, and molecular markers to differentiate between Gyrodactylus salaris Malmberg, 1957 and G. thymalli Žitňan, 1960 (Monogenea: Gyrodactylidae). Parasitology 124, 203-213. DOI : 10.1017/S0031182001001044

Ziętara, M. S. and Lumme, J. (2002). Speciation by host switch and adaptive radiation in a fish parasite genus Gyrodactylus (Monogenea: Gyrodactylidae). Evolution 56, 2445-2458.

Žitňan, R. (1960). Gyrodactylus thymalli sp. nov. from the fins of the grayling (Thymallus thymallus). Helminthologia 2, 266-269. (In German.) 